Creative Commons User License: CC BY-NC-ND

Abstracted by: EBSCOhost, Electronic Journals Service (EJS),

Google Scholar, Journal Seek, Scientific Commons,

Food and Agricultural Organization (FAO), CABI and Scopus

http://eoi.citefactor.org/10.11226/v25i3
Journal of Agricultural Extension

Vol. 25 (3) July, 2021

ISSN(e): 24086851; ISSN(Print); 1119944X

http://journal.aesonnigeria.org

http://www.ajol.info/index.php/jae

Email: editorinchief@aesonnigeria.org

\title{
Role of Extension Forest Officers in Forest Conservation in Cross River State, Nigeria
}

https://dx.doi.org/10.4314/jae.v25i3.7

\author{
Agube, Ejeje Igwe \\ Department of Agricultural Extension and Rural Sociology \\ Faculty of Agriculture, Forestry/Wildlife Resources Management \\ University of Calabar, Cross River State, Nigeria \\ Email: ejejeagube@gmail.com, Phone: +2348062626081

\section{Igbokwe, Edwin M.} \\ Department of Agricultural Extension \\ Faculty of Agriculture \\ University of Nigeria Nsukka, Enugu State, Nigeria \\ Email: Edwin.igbokwe@unn.edu.ng, Phone: +2348034261915
}

\section{Ojo, Oluwasegun Felix}

Department of Agricultural Extension

Faculty of Agriculture

University of Nigeria Nsukka, Enugu State, Nigeria

Email: felix.ojo@unn.edu.ng, Phone: +2347067107174

\section{Abstract}

This study assessed role of extension forest officers in forest conservation in Cross River State, Nigeria. All the forest officers under the employment of the Cross River State Forestry Commission (CRSFC) formed the population of the study. Systematic sampling technique was employed to select 78 respondents for the study out of a population of 314 forest officers. Data were collected through validated structured interview schedule. Data were analyzed using percentage and mean scores. The major effective extension role of forest officers in forest conservation were creating awareness through environmental enlightenment campaign in forest communities $(\bar{x}=2.61)$ and dissemination of information in relation to public participation in forest conservation $(\bar{x}=2.61)$. The Major training needs of forest officers in forest conservation were sustainable forest management practices $(\bar{x}=3.39)$, forestry extension practices $(\bar{x}=3.32)$ and developing group participation. The most serious constraints to effective forestry extension service delivery were inadequate funding $(\bar{x}=2.97)$, and lack of vehicles for field staff logistics $(\bar{x}=2.80)$. ). Forestry extension service delivery in forest conservation was less effective, owing to a great number of constraints militating against the service delivery. For extension role of forest officers in forest conservation to be more effective in the state, there is need for extension unit to be created by the Cross River State Forestry Commission and specifically saddled with the responsibility of carrying out forestry extension functions along with the readiness of the state government to adequately coordinate and fund forestry extension services.

Keywords: Forestry extension, forest officer, forest conservation 
Creative Commons User License: CC BY-NC-ND

Abstracted by: EBSCOhost, Electronic Journals Service (EJS),

Google Scholar, Journal Seek, Scientific Commons,

Food and Agricultural Organization (FAO), CABI and Scopus

http://eoi.citefactor.org/10.11226/v25i3
Journal of Agricultural Extension

Vol. 25 (3) July, 2021

ISSN(e): 24086851; ISSN(Print); 1119944X

http://journal.aesonnigeria.org

http://www.ajol.info/index.php/iae

Email: editorinchief@aesonnigeria.org

\section{Introduction}

Globally, more than one billion hectares (ha) of deforested and degraded forestland are estimated to be available for forest restoration and rehabilitation (Food and Agriculture Organization, 2017), of which Nigeria has her own share. This supports the fear of continuous decline of Nigeria's forests and thus strengthens the call for its conservation both by legislation and programmes. Concern over forest cover in Nigeria has resulted in repeated efforts to protect and increase forest areas in the country by formulations of forest policies across the three tiers of government in collaboration with international organizations like the World Bank, United Nations Environmental Programme (UNEP), Canadian International Development Agency (CIDA), and United Kingdom Department for International Development (DFID) (Cross River State - Reducing Emission from Deforestation and forest Degradation, 2017). Sadly, despite these lofty policies, forest conservation in Nigeria seems to be a mirage.

Highlighting on the importance of forest policy, Udeagha et al., (2016) put forward that forest policy and administration are ideal approaches to fulfill the objectives of furthering rural development, arresting forest degradation and ensuring sustainable forest development In Nigeria, at the national level, many forestry initiatives and programmes have been developed to support sustainable forest management. These include the Nigerian Forestry Action Programme -1996, Inter-ministerial Committee on Desertification and Deforestation Programme - 2000 and National Council on Shelterbelt and Afforestation Programme - 2004 (UN-REDD+, 2015), among others. In spite of a variety of attempts to tackle deforestation and forest degradation through formulation of forest policies with the aim of furthering forest conservation in Nigeria, the country loses between 450,000 and 600,000 hectares of forest to deforestation annually to rank among the countries with the highest rate of deforestation in the world (Adekunle, 2019).

Forest conservation is the practice of planting and maintaining forest areas for the benefit and sustainability of future generations and involves the upkeep of natural resources within a forest cover that are beneficial to both humans and the ecosystems (Pawar \& Ravi, 2015). Highlighting on the aims of conservation, the UNCCD (2019) reported that conservation of biodiversity aims at promoting the sustainable use of natural resources, ecosystems and biodiversity including commitment to socio-economic goals.

Forest conservation efforts of the government through policy and programme initiatives are likely to be more successful if extension service is involved. This is because through forestry extension, the end-users of the forest will be made to know that forests will be better enjoyed by sharing their benefits if sustainably managed. Agricultural extension precedes forestry extension even though same methodologies are employed in both approaches. Vihi, Daudu and Anonguku (2020), posited that agricultural extension is generally viewed as a non-formal educational process aimed at creating desired changes in the knowledge, attitude, skills and behavior of 
Creative Commons User License: CC BY-NC-ND

Abstracted by: EBSCOhost, Electronic Journals Service (EJS), Google Scholar, Journal Seek, Scientific Commons,

Food and Agricultural Organization (FAO), CABI and Scopus
Journal of Agricultural Extension

Vol. 25 (3) July, 2021

ISSN(e): 24086851; ISSN(Print); 1119944X

http://journal.aesonnigeria.org

http://www.ajol.info/index.php/jae

Email: editorinchief@aesonnigeria.org

relevant clienteles. In many countries, extension services represent an example of a formal institution that plays a critical role in supporting small-scale agriculture and in achieving national and household food security (Rickards et al., 2018). In the other hand, forestry extension are programmes designed to meet the needs of small- scale farmers through agro-forestry technology, conservation of small-size log and wood processing technology, scientific information about biodiversity and new concepts in conservation (Agbogidi \& Ofuoku, 2009). Expatiating on its importance, Vihi et al., (2020) see it as an important tool to expand forest resources in a resources poor country, protect its dwindling forest resources, ensure optimum use of forest resources, and maintain both efficiency and equity in forestry development. They further maintained that forestry extension should stem primarily from the need to maintain both efficiency and equity in forestry development as it is the "means" to achieve the "ends"; the adoption of forestry technologies by the villagers for their socio-economic uplift/improvement. The main task of forestry extension is to disseminate necessary information to the clients in order to change their attitudes towards environmental and developmental problems and adopt suitable innovation that can enhance conservation of the forest. Although, Agricultural and forestry extension are always considered parallel activities wherein different institutions are working, forestry extension has much in common with agricultural extension and is based on a number of similar principles (Vihi et al., 2020 \& Udo et al., 2009). Nevertheless, the authors argued that forestry presents different challenges and different emphases from agriculture and concluded that the sure way to protect the forest and its resources is to create awareness among local inhabitants of the importance and value of forest and the need to protect it.

Forestry extension programme involves training activities for communities by forest officers through short- term courses, field visits and practical demonstration in specific areas and disciplines including tree tending techniques, maintenance of hand tools, and sustainable harvesting practices of forests products and interrelationships of the forest components (Agbogidi \& Ofuoku, 2009). This could be achieved by communicating to and educating the people of the protective measures of the forest through extension. This will enable rural people, especially rural forest communities to know that forests will be better enjoyed by sharing their benefits if sustainably managed. Therefore, existing and emerging scientific knowledge about sustainable forest management practices need to be communicated to all forestry stakeholders through forestry extension if the present alarming and increasing rate of deforestation and forest degradation must be reduced in the forest zones of Nigeria, especially in the Cross River rainforest where there is an ongoing logging moratorium policy.

Endowed with a vast forest cover that harbours a great number of rare forest's fauna and flora, Cross River State is reported to be one of the hotpots of biodiversity conservation in the world (National Space and Research Development Agency \& $\mathrm{FAO}, 2015)$. At the same time, it is one of the hotspots of wanton deforestation and forest degradation among forest dependent states in Nigeria, despite a number of policies and programmes in place governing the use of forest resources. Chiefly 
Creative Commons User License: CC BY-NC-ND

Abstracted by: EBSCOhost, Electronic Journals Service (EJS),

Google Scholar, Journal Seek, Scientific Commons,

Food and Agricultural Organization (FAO), CABI and Scopus
Journal of Agricultural Extension

Vol. 25 (3) July, 2021

ISSN(e): 24086851; ISSN(Print); 1119944X

http://journal.aesonnigeria.org

http://www.ajol.info/index.php/jae

Email: editorinchief@aesonnigeria.org

among the forest policies in existence is the logging ban policy. Despite the ongoing logging ban since 2009, the state's rainforest has witnessed further unprecedented drastic decline, chiefly due to illegal logging and agricultural expansion (Alobi et al; 2020). Accordingly, there is a prediction that Cross River State forest cover would drop from 642,195 hectares in 2014 to 550,000 hectares by 2040 (NSRDA \& FAO, 2015), indicating a steady increase in deforestation rate over the years under review. Given the current statistical scenario, it is worrisome that the unrestrained and uncontrolled deforestation and forest degradation across the state is causing devastating impacts on the environment and undermining the livelihood of over millions of rural people who depend on forest resources. This raises concerns among individuals, forest stakeholders, governments and forestry experts as to whether this trend is as a result of the ineffectiveness or absence of forestry extension services in the state.

\section{Objectives of the Study}

The broad objective of this study was to assess role of extension forest officers in forest conservation in Cross River State. Specifically, the paper was premised on the following objectives:

(i) examine the effectiveness of extension role of forest officers in forest conservation;

(ii) identify forest officers' extension training needs in forest conservation; and

(iii) identify forest officers' constraints militating against forestry extension service delivery.

\section{Methodology}

The study was conducted in Cross River State (CRS), Nigeria. The state lies within longitude $4^{0} 50^{\prime}$ and $9^{0} 28^{\prime}$ east of the Greenwich Meridian and latitude $5^{0} 23^{\prime}$ and $4^{0}$ 27 ' north of the equator. The National Population Census (2016) projected the population of the state at 3,862 634. Cross River State is made up of 18 Local Government Areas (LGAs). Under the Cross River State Agricultural Development Programme, the state is divided into three agro-ecological zones which include the mangrove and the swamp forests which cover the Calabar Agricultural zone, tropical rainforest of Ikom Agricultural Zone and derived and guinea savannah belts of Ogoja Agricultural Zone. The tropical rainforest dominates the southern and central parts of the state. The major occupation of the people is farming and major arable crops include cassava, yam, rice, cocoyam, maize and groundnut. The population of the study comprised all forest officers under the employment of Cross River State Forestry Commission (CRSFC). A systematic random sampling procedure was employed to select 78 forest officers out of a sampling frame of 314 forest officers in the state's Forestry Commission, representing $25 \%$ of the population randomly selected for the study. Structured interview schedule was used to elicit data from the forest officers. Out of 78 instruments administered to the respondents, only 74 were recovered and used for data analysis.

To examine the effectiveness of extension role of forest officers in forest conservation (objective 1), the variables were captured using a 4- point Likert type 
Creative Commons User License: CC BY-NC-ND

Abstracted by: EBSCOhost, Electronic Journals Service (EJS),

Google Scholar, Journal Seek, Scientific Commons,

Food and Agricultural Organization (FAO), CABI and Scopus
Journal of Agricultural Extension

Vol. 25 (3) July, 2021

ISSN(e): 24086851; ISSN(Print); 1119944X

http://journal.aesonnigeria.org

http://www.ajol.info/index.php/jae

Email: editorinchief@aesonnigeria.org

scale with response categories of very effective $=4$, effective $=3$, less effective $=2$ and not effective at all $=1$. The cut-off mean value for decision rule was 2.5 . Items with mean values above or equal 2.5 were considered as effective forestry extension role of forest officers in forest conservation while items below 2.5 were considered otherwise. To identify forest officers' extension training needs in forest conservation (objective 2), the variables were captured using a 4-point Likert type scale with response categories of Strongly Agree $=4$, Agree $=3$, Disagree $=2$ and strongly Disagree $=1$. A mean score of 2.5 and above indicated areas of training needs while a mean score lower than 2.5 indicated areas where training were not needed. To identify the constraints militating against forestry extension service delivery in the state (objective 3 ), the variables were captured using a 3-point rating scale with response categories of major constraint $=3$, minor constraint $=2$, and not a constraint $=1$. A mean value of 2.0 was obtained. Items with mean value equal or above 2.0 were considered as major constraints affecting forestry extension delivery, while items with mean value below 2.0 were considered otherwise. Variables of objectives 1 -3 were analyzed using mean scores.

\section{Results and Discussion}

\section{Perceived Effectiveness of Extension Roles of Forest Officers in Forest Conservation}

Table 1 shows the result of the effectiveness of extension role of forest officers in forest conservation as perceived by forest officers in the study area. The results shows that the roles considered effective according to the magnitude of the mean scores were: creation of awareness and carrying out environmental enlightenment campaign at forest community level in forest conservation $(\bar{x}=2.62)$; dissemination of information in relation to public participation in forest conservation $(\bar{x}=2.61)$; field visits to forest community and practical demonstration in specific forestry areas $(\bar{x}=2.60)$; and teaching rural dwellers in local language on forest conservation $(\bar{x}=2.59)$. Other effective extension roles of forest officers in forest conservation include: carrying out tree planting campaign and seminars with saw-millers/timber dealers $(\bar{x}=2.58)$; and presentation of conservation programmes in mass media for public viewing $(\bar{x}=2.55)$. However, other extension role of forest officers such as assist farmers in agro forestry practices $(\bar{x}=1.95)$, educate and warn forest dwellers about the illegality of deforestation and forest degradation/encroachment $(\bar{x}=1.93)$, among other roles were considered as ineffective.

The result implies that forestry extension service delivery is very low and somewhat ineffective given that only a few roles were perceived effective. This could be linked to the reason why there is a steady upscale in deforestation and forest degradation activities as against adoption of forest conservation measures across the forest belts of the state. Abdullahi et al., (2017) were of the view that extension service can play vital role in assisting rural forest communities in implementing policies and 
Creative Commons User License: CC BY-NC-ND

Abstracted by: EBSCOhost, Electronic Journals Service (EJS), Google Scholar, Journal Seek, Scientific Commons,

Food and Agricultural Organization (FAO), CABI and Scopus
Journal of Agricultural Extension

Vol. 25 (3) July, 2021

ISSN(e): 24086851; ISSN(Print); 1119944X

http://journal.aesonnigeria.org

http://www.ajol.info/index.php/jae

Email: editorinchief@aesonnigeria.org

programmes that deal with deforestation mitigation. In the context of forest conservation, forestry extension has a responsibility to increase awareness through communication and education of the best available measures that can be used to conserve the forest. This follows the views of Antwi-Agyei et al., (2018) and Juhola et al., (2016), that extension has the responsibility of assisting rural people to avoid mal-adaptation practices such as deforestation and forest degradation. This ineffectiveness of most forest officers' roles in forest conservation pose grave consequences for the state's forest and forest communities. On the other hand, effective forestry extension has the capacity to enlighten the forest communities on the inherent dangers their activities pose to the environment thereby stimulating compliance with existing forestry laws and regulations, such as the existing logging ban policy in the state. In this regard, if the state's forestry Commission is committed to saving the rainforest and achieving Sustainable Forest Management (SFM), which has always been the goal of foresters, then aggressive forestry extension is a must.

From the result, forest officers claimed to have effectively carried out a few extension role in forest conservation, howbeit, these effective roles may not have had much impacts on forest community people since there is a steady increase in deforestation activities in the state. Meanwhile, two key points were observed during the administration of the instrument. Firstly, there are no designated forestry extension officers in the state's Forestry Commission, rather, forest guards, forest rangers and other forest officers are often engaged in forestry extension activities. Secondly, forestry is divorced from the general agriculture and therefore any extension function is carried out by staff of the state's forestry commission only. On the whole, the findings corroborate that of Vihi et al., (2020) who reported that only a few forestry extension services that were adjudged as satisfactory by the respondents and thus forestry extension delivery in forest conservation was considered very low since the respondents expressed dissatisfaction with most of the forestry extension services delivered, especially services such as training on agro-forestry, raising of seedlings, and forest management practices etc. 
Creative Commons User License: CC BY-NC-ND

Abstracted by: EBSCOhost, Electronic Journals Service (EJS),

Google Scholar, Journal Seek, Scientific Commons,

Food and Agricultural Organization (FAO), CABI and Scopus

http://eoi.citefactor.org/10.11226/v25i3
Journal of Agricultural Extension

Vol. 25 (3) July, 2021

ISSN(e): 24086851; ISSN(Print); 1119944X

http://journal.aesonnigeria.org

http://www.ajol.info/index.php/iae

Email: editorinchief@aesonnigeria.org

\section{Table 1: Effectiveness of extension role of forest officers in forest conservation}

\begin{tabular}{lll}
\hline Extension role in forest conservation & Mean & SD \\
\hline Environmental enlightenment campaign at forest community level & $2.62^{*}$ & 0.69 \\
Dissemination of information in relation to public participation in forest conservation & $2.61^{*}$ & 0.69 \\
& & \\
& $2.60^{*}$ & 0.69 \\
Field visits to forest community and practical demonstration in specific forestry & & \\
areas & $2.59^{*}$ & 0.79 \\
Teaching rural dwellers in local language on the conservation forest & $2.58^{*}$ & 0.68 \\
Tree planting campaign and seminar with saw-millers/timber dealers & $2.55^{*}$ & 0.86 \\
Presentation of conservation programmes in mass media for public viewing & 1.98 & 0.76 \\
Establishment of pilot schemes for woodlots to encourage private plantations & & \\
& 1.95 & 0.72 \\
Assist farmers in agro forestry practices & 1.94 & 0.75 \\
Formation of young forester club in secondary schools & 1.93 & 0.74 \\
Educate and warn forest dwellers about the illegality of forest & & 0.84 \\
degradation/encroachment & 1.91 & 0.74 \\
Supply free seedlings to forest population and assisting in raising nurseries and & & 0.72 \\
tree planting techniques & 1.90 & 0.75 \\
School extension in forest conservation & 1.89 & 0.75 \\
Promotion of rural afforestation/regeneration programmes & 1.81 & 0.78 \\
& & 1.71 \\
Hold seminars/workshop with forest management committee & 1.70 & 0.88 \\
\hline Educating rural dwellers about the effects of bush burning on the environment & & \\
\hline
\end{tabular}

\section{Source: Field data, 2019; *effective}

\section{Extension Training Needs of Forest Officers in Forest Conservation}

Rankings based on mean values arranged in descending order as depicted in Table 2 indicates that the major areas of extension training needs of forest officers in forest conservation were: sustainable forest management practices $(\bar{x}=3.39)$; forestry extension practices $(\bar{x}=3.32)$; forest inventory $(\bar{x}=3.30)$; developing group participation (Mean $\bar{x}=3.23$ ); communication skills $(\bar{x}=3.22)$; basic mensuration techniques $(\bar{x}=3.20)$; biodiversity management/monitory $(\bar{x}=3.19)$; wildlife management monitory $(\bar{x}=3.16)$; plantation establishment/management $(\bar{x}=3.15)$; and developing group dynamics $(\bar{x}=3.14)$.

The result implies that all the training needs indicated were areas of extension training needs of forest officers in forest conservation in the state. This indicates that forest officers need training in attitude, skill and knowledge to meet the needs and ensure satisfactory standards of performance. The reason why forest officers required training in all the areas identified could be linked to the fact that efficient delivery of extension services to forest communities requires that extension officers have good knowledge and understanding in all areas of forestry. This could inform some of the conservation interventions and technologies that are delivered to the clienteles. One of the factors that influence forest conservation is extension, technical assistance and training. Sigh and Javachandran (2018) were of the view 
Creative Commons User License: CC BY-NC-ND

Abstracted by: EBSCOhost, Electronic Journals Service (EJS), Google Scholar, Journal Seek, Scientific Commons,

Food and Agricultural Organization (FAO), CABI and Scopus
Journal of Agricultural Extension

Vol. 25 (3) July, 2021

ISSN(e): 24086851; ISSN(Print); 1119944X

http://journal.aesonnigeria.org

http://www.ajol.info/index.php/jae

Email: editorinchief@aesonnigeria.org

that training should be able to equip the forestry officers with requisite problemsolving skills with established abilities to analyze the problem, think critically about available options, take well informed decisions, and communicate those decisions clearly to the clienteles. This heightens the need for adequate training of forest officers in key forestry areas for effective service delivery. To this end, field foresters need to understand disciplines that earlier generations of foresters may not have emphasized including forest ecology, anthropology, forest economics, forest pathology, etc. Training on these specific aspects of needs for forest workers may help protect the state's rainforest. The findings corroborate with that of Sigh and Javachandran (2018), who reported that training needs analysis for state forest service officers revealed need of a holistic and scientific training design to create an enhanced sense of appreciation towards ecosystems and the ecological approach towards forest management, such as forest survey and techniques, nursery and plantation techniques, forest economics, programme evaluation and monitoring, communication skills, forest management and forest laws and regulations etcetera in India.

\section{Table 2: Extension training needs of forest officers in forest conservation}

\begin{tabular}{|c|c|c|}
\hline Areas of training needs & Mean & SD \\
\hline Sustainable forest management practices & $3.39^{*}$ & 0.76 \\
\hline Forestry extension practices & $3.32^{*}$ & 0.86 \\
\hline Forest inventory & $3.30^{*}$ & 0.87 \\
\hline Developing group participation & $3.23^{*}$ & 0.84 \\
\hline Communication skills & $3.22^{*}$ & 0.96 \\
\hline Basic mensuration techniques & $3.20^{*}$ & 0.79 \\
\hline Biodiversity management/monitory & $3.19^{*}$ & 0.84 \\
\hline Wildlife management monitory & $3.16^{*}$ & 0.86 \\
\hline Plantation establishment/management & $3.15^{*}$ & 1.00 \\
\hline Developing group dynamics & $3.14^{*}$ & 0.78 \\
\hline Forest economy & $3.12^{*}$ & 0.98 \\
\hline Programme evaluation and monitoring & $3.11^{*}$ & 0.96 \\
\hline Prevention of forest encroachment and enforcement of environmental law & $3.11^{*}$ & 0.97 \\
\hline Techniques in conflict management & $3.10^{*}$ & 0.88 \\
\hline Forest anthropology/ forest pathology & $3.08^{*}$ & 0.92 \\
\hline Reportage of forest events and other developmental activities & $3.08^{*}$ & 0.82 \\
\hline Construct, maintain and operate forest nursery & $3.04^{*}$ & 1.05 \\
\hline Skills in public awareness campaign & $3.04^{*}$ & 1.05 \\
\hline Data gathering and storage techniques & $3.01^{*}$ & 1.03 \\
\hline New tools for rural appraisal & $2.92^{*}$ & 0.95 \\
\hline
\end{tabular}

Source: Field data, 2019; *areas of training needs 
Creative Commons User License: CC BY-NC-ND

Abstracted by: EBSCOhost, Electronic Journals Service (EJS),

Google Scholar, Journal Seek, Scientific Commons,

Food and Agricultural Organization (FAO), CABI and Scopus
Journal of Agricultural Extension

Vol. 25 (3) July, 2021

ISSN(e): 24086851; ISSN(Print); 1119944X

http://journal.aesonnigeria.org

http://www.ajol.info/index.php/jae

Email: editorinchief@aesonnigeria.org

http://eoi.citefactor.org/10.11226/v25i3

Forest Officers' Perceived Constraints to Forestry Extension Service Delivery

Table 3 shows that forest officers in Cross River state perceived all identified constraints as major constraints. Rankings based on mean values revealed that five (5) major constraints to forestry extension delivery of extension officers in the state were: inadequate funding $(\bar{x}=2.97)$; lack of vehicles for field staff logistics $(\bar{x}=2.80)$; inadequate staff strength $(\bar{x}=2.72)$; poor salary structure of forest extension staff ( $\bar{x}=2.72$ ); poor incentives/allowances for field staff $(\bar{x}=2.66)$; and instability in government policy/institutional arrangements in extension $(\bar{x}=2.66)$. However, among the least ranked major constraints to forestry extension delivery include: seedlings inadequacy $(\bar{x}=2.2)$; and problems of fire outbreak $(\bar{x}=2.14)$.

The reason why forest officers perceived all identified constraints to be major constraints affecting forestry extension delivery may be linked to the fact that majority must have spent a great a number of years in the service and therefore must have had more knowledge and experience in the problems inherent in the job. Inadequate funding of the research sector is the bane of extension service development in Nigeria. Presently, Nigerian education and research sectors are constrained with serious financial crisis. As a result, important developmental and expansion plans in most research institutions, especially extension service, have been curtailed and the quality of work impaired. Supporting this view, Hamisu et al., (2017 was also of the view that the most difficult and challenging policy issue facing the agricultural extension service today is how to secure a stable source of funding. Forestry extension programme needs adequate funding and coordination to ensure successful extension service delivery. Poor logistic support of field staff is a consistent constraint to extension service delivery. This has hampered the transportation of field forest officers to their duty posts and supply of work materials to carry out their roles. Transportation of field staff is therefore very essential in operating an efficient forestry extension service.

The finding is in conformity with that of Vihi et al., (2020) who reported that the constraints perceived to limit effective forestry extension service delivery include lack of funding of extension services, inadequate number of extension agents, lack of transport facilities and lack of in-service training of personnel in Plateau State, Nigeria. 
Creative Commons User License: CC BY-NC-ND

Abstracted by: EBSCOhost, Electronic Journals Service (EJS),

Google Scholar, Journal Seek, Scientific Commons,

Food and Agricultural Organization (FAO), CABI and Scopus

http://eoi.citefactor.org/10.11226/v25i3
Journal of Agricultural Extension

Vol. 25 (3) July, 2021

ISSN(e): 24086851; ISSN(Print); 1119944X

http://journal.aesonnigeria.org

http://www.ajol.info/index.php/jae

Email: editorinchief@aesonnigeria.org

Table 3: Perceived constraints to forestry extension service delivery in forest conservation

\begin{tabular}{llc}
\hline Constraints & Mean & \\
& & SD \\
\hline Inadequate funding & $2.97^{*}$ & 0.16 \\
Lack of vehicles for field staff logistics & $2.80^{*}$ & 0.41 \\
Inadequate staff strength & $2.72^{*}$ & 0.54 \\
Poor salary structure of forest extension staff & $2.72^{*}$ & 0.51 \\
Poor incentives/allowances for field staff & $2.66^{*}$ & 0.53 \\
Instability in government policy/institutional arrangements in & $2.66^{*}$ & 0.58 \\
extension & $2.53^{*}$ & 0.60 \\
Extension service mandates in the three tiers of government are & & \\
unclearly defined. & $2.47^{*}$ & 0.58 \\
Lack of capacity building/training & $2.39^{*}$ & 0.70 \\
Lack of strong public support & $2.35^{*}$ & 0.56 \\
Inadequate public address system & $2.31^{*}$ & 0.76 \\
Communication barriers between forest officers and clienteles & $2.30^{*}$ & 0.59 \\
Inadequate clientele participation in forestry programme & & \\
development & $2.26^{*}$ & 0.64 \\
Lack of cameras, chemicals and other photographic and printing & & \\
materials & $2.20^{*}$ & 0.76 \\
Seedlings inadequacy & $2.14^{*}$ & 0.75 \\
\hline Problems of fire outbreak & &
\end{tabular}

Source: Field data, 2019; ${ }^{*}$ major constraints

\section{Conclusion and Recommendation}

Forestry extension service in forest conservation in the state is grossly less effective owing to a number of constraints such as inadequate funding, lack of vehicles for field staff logistic, and inadequate seedlings supply militating against forestry extension service delivery in the state. Also, forest officers had many areas of training needs in forestry extension such as sustainable forest management practices, forestry extension practices, forest inventory, developing group participation, communication skills, among other areas of training needs.

The conservation of forests depends on the effectiveness of forestry extension service delivery to forest communities. Therefore, forestry extension services should be intensified as well as thoroughly coordinated. For the extension role of forest officers to be more effective in the state, forestry extension unit should be created by the CRSFC in addition to other existing units and saddled specifically with the responsibility of carrying out forestry extension functions with the readiness of the state government to adequately coordinate and fund forestry extension programmes. The Cross River State Forestry Commission should organize periodic trainings in forestry extension for forest officers for effective service delivery in forest conservation if sustainable forest management is to be achieved. For the 
Creative Commons User License: CC BY-NC-ND

Abstracted by: EBSCOhost, Electronic Journals Service (EJS), Google Scholar, Journal Seek, Scientific Commons,

Food and Agricultural Organization (FAO), CABI and Scopus

http://eoi.citefactor.org/10.11226/v25i3
Journal of Agricultural Extension

Vol. 25 (3) July, 2021

ISSN(e): 24086851; ISSN(Print); 1119944X

http://journal.aesonnigeria.org

http://www.ajol.info/index.php/jae

Email: editorinchief@aesonnigeria.org

effectiveness of forestry extension service in forest conservation in the state, the constraints to the service delivery must be seriously worked on, in terms of adequate funding, provision of logistics, adequate staff strength and capacity building and training of field forest officers in forest conservation.

\section{References}

Abdullahi, A., Girel, A., Usman, I., and Abubakar, M.G. (2017). Assessment of adaptation strategies for deforestation and climate: Implication for Agricultural Extension System in Nigeria. International Journal of Innovative Agriculture and Biology Research, 5(2): 11-17.

Adekunle P. (2019). Nigeria among countries with high deforestation rate globally NEWMAP. Retrieved $5^{\text {th }}$ July, 2021 - https://punchng.com/Nigeria-among-countrieswith-high-deforestation-rate-globally-NEWMAP/.

Agbogidi, O. M., \& Ofuoku, A. U. (2009). Forestry extension: Implications for forest protection. International Journal of Biodiversity and Conservation, 5(10): 098 - 104.

Alobi, A., Ogar, D. \& Anoh, R. (2020). Perception of forest stakeholders on logging ban in Cross River State, Nigeria. Asian Journal of Research in Agriculture and Forestry, 5(2): $1-15$.

Antwi-Agyei, P., Dougill, A.J., Stringer, L.C., Codjoe, S.N.A., (2018). Adaptation opportunities and maladaptive outcomes in climate vulnerability hotspots of northern Ghana. Clim. Risk Manage. 19, 83-93.

Food and Agriculture Organization (2017). Forest restoration and rehabilitation: Basic Knowledge. Rome: FAO - Gender Team in Forestry Unit.

Hamisu S, Ardo AM, Makinta MM, Garb L, Musa G. (2017). A review on current status of Agricultural Extension Service in Nigeria. Asian Journal of Advances in Agricultural Research, 1(3):1-8.

Juhola, S., Glass, E., Linner, B.-O., Neset, T.-S., (2016). Redefining maladaptation. Environ. Sci. Policy, 55, 135-140.

National Population Census (2016). Nigeria 2006 Census Figures. Masterweb.com/Nigeria 2006 census figss.html, Retrieved $6^{\text {th }}$ July, 2019.

National Space Research and Development Agency (NSRDA) \& FAO (2015). Report on the drivers of deforestation and forest degradation in Cross River State. UN-REDD Programme, Nigeria.

Pawar, K. \& Ravi, V. (2015). Forest conservation and environmental awareness. Procedia Earth and Planetary Science, 11: 212 -215.

Rickards, L., Alexandra, J., Jolley, C., Frewer, T. (2018). Final report: review of agricultural extension. Australian Centre for International Agricultural Research (ACIAR), 5(2): 50 -72 . 
Creative Commons User License: CC BY-NC-ND

Abstracted by: EBSCOhost, Electronic Journals Service (EJS), Google Scholar, Journal Seek, Scientific Commons,

Food and Agricultural Organization (FAO), CABI and Scopus

http://eoi.citefactor.org/10.11226/v25i3
Journal of Agricultural Extension

Vol. 25 (3) July, 2021

ISSN(e): 24086851; ISSN(Print); 1119944X

http://journal.aesonnigeria.org

http://www.ajol.info/index.php/jae

Email: editorinchief@aesonnigeria.org

Singh M. \& Javachandran k. (2018). Training needs analysis for induction training of state forest service officers. India Foresters, 144(2): 105 - 116.

Turyahabwe, N., Byakagaba, P., \& Tumusiine, D. (2015). Decentralization of forest management: Is it a panacea to challenges in forest governance in Uganda? Book chapter in Precious forest - forest earth, InTech, 114 - 130.

Udeagha, A. U., Ulocha, O. B., \& Stephen, S. A. (2016). Forest policy and administration in Nigeria: Lessons from Tanzania. International Journal of Agriculture and Rural Development, 19 (1): 2399 - 2406.

Udo E. S., Udofia, S.I. \& Olajide O. (2009). Timber dealers' perception of their knowledge of the forest law in Uyo senatorial district of Akwalbom State. Nigeria African Research Review Journal, 3(1):125-135.

United Nations Convention to Combat Desertification (UN-CCD) (2019). Report on land degradation Neutrality for biodiversity conservation goals. UNCCD International, Rome. Retrieved $4^{\text {th }}$ July, 2021 - https:/www.un.ccd.int/news-events/report-idncontributing-global-biodiversity-conversation-goals-o.

United Nations Reducing Emission from Deforestation and Forest Degradation (2017). Natural resources and sustainable forest management: Towards a REDD+ Strategy for Cross River State.Reports prepared for the REDD+ Strategy Programme, Nigeria. Retrieved $26^{\text {th }}$ April, 2019 - https://www.unredd.net>alia.

United Nations Reducing Emission from Deforestation and Forest Degradation (2015). Using spatial analysis to explore multiple benefits from REDD+ in Cross River State. Retrieved $26^{\text {th }}$ April, 2019 - https://www.unredd.net>alia.

Vihi, S. K., Daudu, S. \& Anonguku I. (2020). Assessment of forestry extension service delivery among rural farmers in Plateau State, Nigeria. Asian Journal of Research in Agriculture and Forestry, 6(1): $12-24$. 